\title{
Emphysema following vitrectomy with fluid-gas exchange: description of a rare complication
}

This article was published in the following Dove Press journal:

Clinical Ophthalmology

II February 2014

Number of times this article has been viewed

\section{Eduardo F Damasceno' Nadyr Damasceno ${ }^{2}$ \\ Soraya Horowitz ${ }^{2}$ Marcio Mortera Rodrigues ${ }^{3}$ \\ 'Universidade Federal Fluminense, Niterói, Brazil; ${ }^{2}$ Hospital Naval Marcílio Dias, Rio de Janeiro, Brazil; ${ }^{3}$ Universidade Federal do Rio de Janeiro, Rio de Janeiro, Brazil}

Correspondence: Eduardo F Damasceno Universidade Federal Fluminense School of Medicine, Marques do Paraná 303, Niteroi, Brazil

Tel +552 I 25687728

$\mathrm{Fax}+552125690304$

Email e_damasceno@yahoo.com
Purpose: To report a case of subcutaneous emphysema involving the orbit, mediastinum, and face after pars plana vitrectomy with fluid-gas exchange.

Methods: Case report of a 55-year-old man who presented with bilateral eyelid and face edema and dysphagia in the immediate postoperative period after pars plana vitrectomy. Orbital and chest computed tomographies were performed, revealing emphysema of the orbit and soft tissue of the face, extending from the neck to the upper chest.

Results: The patient with a retinal detachment in the right eye underwent 23-gauge vitrectomy surgery with fluid-gas exchange and an implantation of silicone oil. The patient had a previous history of facial trauma for more than 20 years with an orbital fracture. After surgery, the patient developed emphysema of the orbit, soft tissue of the face and upper chest. Systemic prophylactic antibiotics associated with antibiotics and steroid drops performed a satisfactory evolution.

Conclusion: The fluid-gas exchange during pars plana vitrectomy in patients with orbital fracture can lead to emphysema of the face, chest, and soft tissue.

Keywords: vitrectomy complications, fluid-gas exchange, orbital emphysema, mediastinal emphysema, face emphysema, orbit fracture

\section{Introduction}

Introduced for the first time by Claus Eckardt, the 23-gauge transconjunctival vitrectomy technique is commonly accepted by vitreoretinal surgeons as a way to treat retinal detachment. ${ }^{1}$

Fluid-gas exchange is an important step of vitrectomy surgery. It occurs with positive air pressure before the implantation of silicone oil into the vitreous cavity. Complication about this step of that surgery has no description in the literature. ${ }^{2,3}$

\section{Case report}

A 55-year-old man presented with bilateral eyelid and face edema, dysphagia, dysphonic voice, and mild dyspnea 30 minutes after a 23-gauge vitrectomy surgery with fluid-gas exchange. A slit-lamp examination presented with bilateral eyelid edema. A single X-ray image of the thorax and neck also confirmed the semiologic aspects (Figure 1A and B). The air infiltration of the soft tissue demonstrated crepitating of the soft tissue to digital press on the face, extending to the neck and upper chest. The patient underwent an orbital computed tomography scan that revealed the presence of emphysema of the orbit and bilateral soft tissue on the face (Figure 2A). 
A

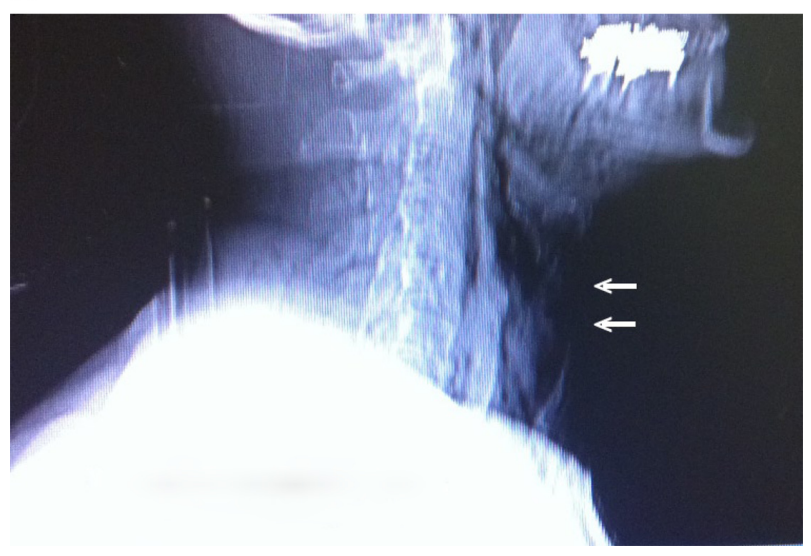

B

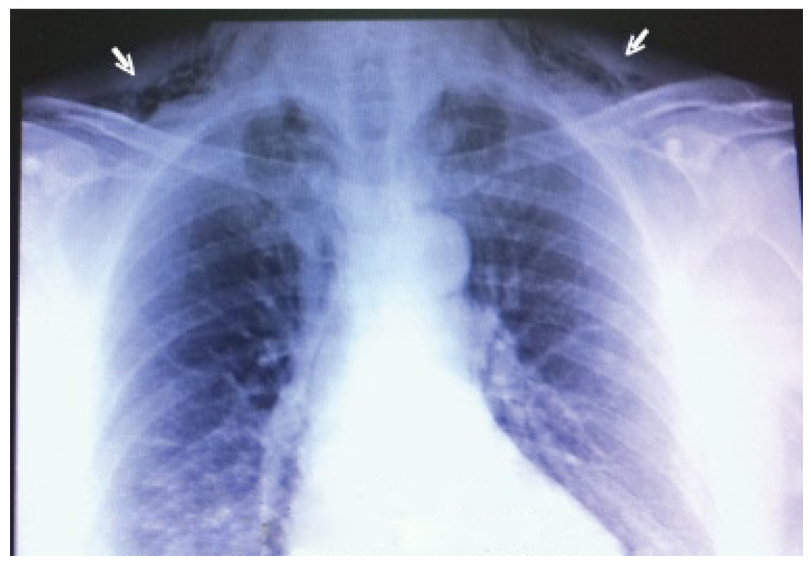

Figure I (A) X-ray of neck lateral incidence. (B) X-ray AP incidence.

Notes: (A) Neck emphysema on the anterior side (arrows); (B) neck and mediastinal emphysema (arrows).

Abbreviation: AP, anteroposterior.

The patient had a past history of face trauma for more than 20 years, with orbital fracture of the floor. This fracture was not previously correct by surgery and is considered as a scar nowadays (Figure 2B).

The patient was hospitalized for clinic observation, cardiac evaluation, blood testing, and prophylactic antibiotic therapy for one week. All signs of compressed anatomical structures by subcutaneous emphysema (dysphagia, dyspnea, and dysphonia) had ceased at the time of discharge, and the patient was in improved and stable condition. Postoperatively, at 3 months, the retina was flat with good intraocular pressure (IOP) control and no evidence of orbital infection.

\section{Discussion}

Orbital emphysema is generally a benign, self-limited condition, most commonly associated with trauma or surgery involving the sinuses or the orbits. ${ }^{4}$ Reports of orbital emphysema without orbital fracture are rare, with reported causes

\section{A}

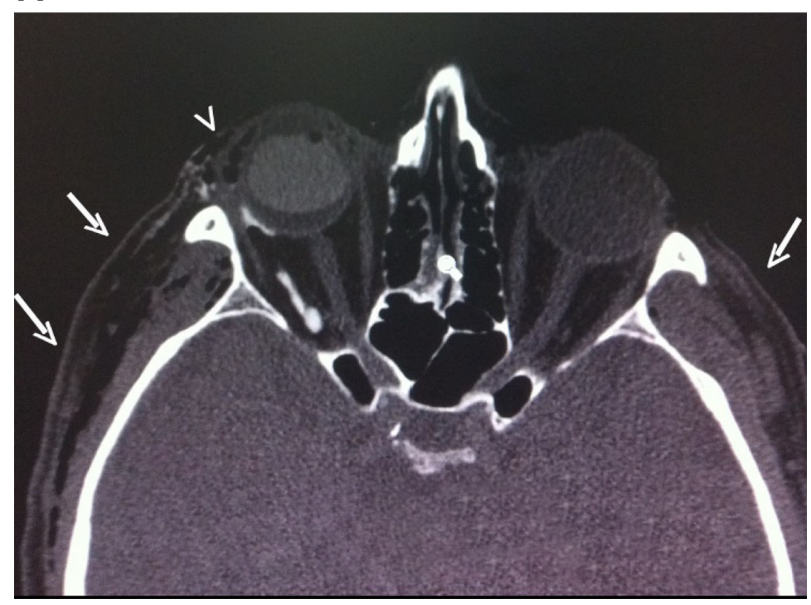

B

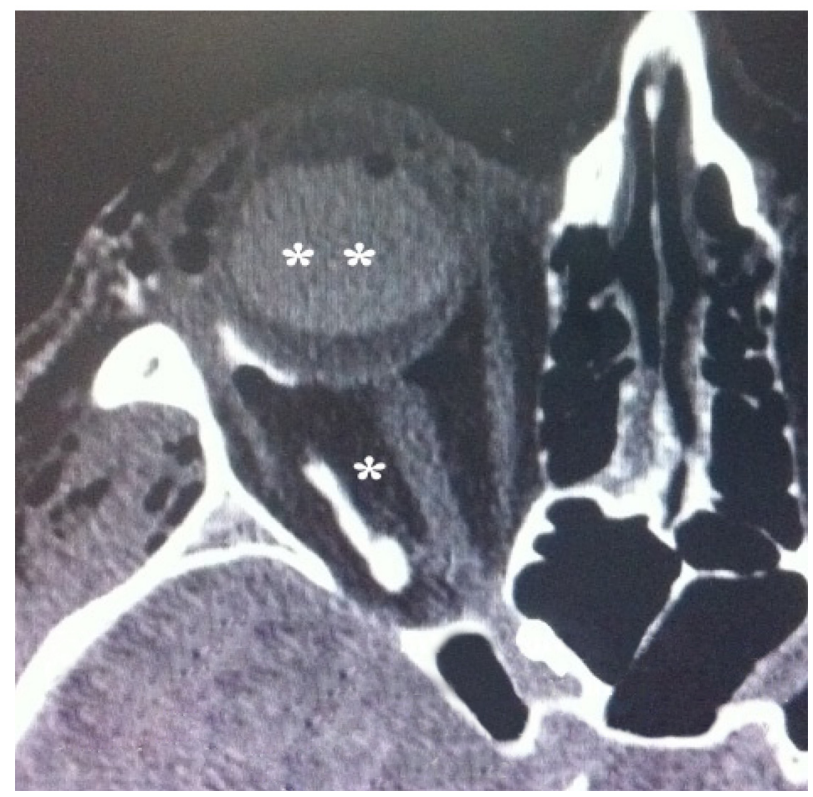

Figure 2 Orbital CT scan.

Notes: (A) Orbital CT scan, coronal incidence. Face bilateral emphysema on the soft tissue (large arrows) and orbital and subconjunctival emphysema too (small arrows). (B) Image detail. Ancient orbital fracture sequela (asterisk) and silicon oil into the vitreous cavity (double asterisks).

Abbreviation: CT, computed tomography.

including compressed blast trauma over the eye, extension to the eyes of massive subcutaneous emphysema in the setting of a large bronchopleural fistula, and positive pressure mechanical ventilation..$^{5-7}$

Although unusual, there is a report in the literature of an air systemic embolism following vitrectomy with fluidgas exchange due to the same positive pressure mechanical ventilation. ${ }^{8,9}$

In this case, we believe that the emphysema resulted from the high gas pressure during fluid-gas exchange associated with the orbital fracture. As orbital emphysema 
usually results from a fracture of the orbit bones allowing air to travel from the paranasal sinus into the orbit, ${ }^{4,5}$ the old fracture of the orbit bones allowed air to travel from the eye into the soft tissue, orbit, and chest. The soft tissue emphysema on the face was so wide that the emphysema was bilateral.

The authors recognize that the physiopathological mechanism to cause the emphysema is theoretical and controversial, because the only source of positive air pressure during the surgery was the fluid-gas exchange. The ocular anesthesia was performed under peribulbar block without any mechanical ventilation support.

We conclude that air infusion during the fluid-gas exchange for pars plana vitrectomy may be complicated by the emphysema of the surrounding structures and that vitreoretinal surgeons should be aware of the possibility of such a complication.

However, there was a good evolution on a follow-up of 3 months with the reattached retina, no sign of orbital infection, and good IOP control during all the postoperative period.

The authors hope to contribute with this work to avoid this kind of complication.

\section{Disclosure}

Authors declare there are no conflicts of interest in this work.

\section{References}

1. Eckardt C. Transconjunctival sutureless 23-gauge vitrectomy. Retina. 2005;25(2):208-211.

2. Thompson JT. Advantages and limitations of small gauge vitrectomy. Surv Ophthalmol. 2011;56(2):162-172.

3. Parolini B, Prigione G, Romanelli F, Cereda MG, Sartore M, Pertile G. Postoperative complications and intraocular pressure in 943 consecutive cases of 23-gauge transconjunctival pars plana vitrectomy with 1-year follow-up. Retina. 2010;30(1):107-111.

4. Hunts JH, Patrinely JR, Holds JB, Anderson RL. Orbital emphysema. Staging and acute management. Ophthalmology. 1994;101(5) 960-966.

5. Cartwright MJ, Ginsburg RN, Nelson CC. Tension pneumoorbitus. Ophthal Plast Reconstr Surg. 1992;8(4):303-304.

6. Li T, Mafee MF, Edward DP. Bilateral orbital emphysema from compressed air injury. Am J Ophthalmol. 1999;128(1):103-104.

7. Upadhyay D, Sporn PH. Orbital emphysema in COPD with bronchopleural fistula. Int J Chron Obstruct Pulmon Dis. 2007;2(2):187-188.

8. Ledowski T, Kiese F, Jeglin S, Scholz J. Possible air embolism during eye surgery. Anesth Analg. 2005;100(6):1651-1652.

9. Ruest P, Aroichane M, Cordahi G, Bureau N. Possible venous air embolism during open eye surgery in a child. Can J Anaesth. 2007;54(10): $840-844$.
Clinical Ophthalmology

\section{Publish your work in this journal}

Clinical Ophthalmology is an international, peer-reviewed journal covering all subspecialties within ophthalmology. Key topics include: Optometry; Visual science; Pharmacology and drug therapy in eye diseases; Basic Sciences; Primary and Secondary eye care; Patien Safety and Quality of Care Improvements. This journal is indexed on

Submit your manuscript here: http://www.dovepress.com/clinical-ophthalmology-journal

\section{Dovepress}

PubMed Central and CAS, and is the official journal of The Society of Clinical Ophthalmology (SCO). The manuscript management system is completely online and includes a very quick and fair peer-review system, which is all easy to use. Visit http://www.dovepress.com/ testimonials.php to read real quotes from published authors. 